\title{
Meanings of living with a chronic wound: a meta-synthesis study
}

\author{
Significados de viver com ferida crônica: estudo de metassíntese
}

Significados de vivir con una herida crónica: estudio de meta-síntesis

Wilkslam Alves de Araújo', Wagner Couto Assis', Alba Benemérita Alves Vilela', Rita Narriman

Silva de Oliveira Boery ${ }^{1}$, Vanda Palmarella Rodrigues ${ }^{1}$, Roseanne Montargil Rocha ${ }^{1, *}$

ORCID IDS

Araújo WA (D) https://orcid.org/0000-0002-3323-4650

Assis WC (D) https://orcid.org/0000-0001-7802-2443

Vilela ABA (D) http://orcid.org/0000-0003-2110-1751

Boery RNSO (D) https://orcid.org/0000-0002-7823-9498

Rodrigues VP (D) https://orcid.org/0000-0002-5689-5910

Rocha RM (iD https://orcid.org/0000-0001-5766-413X

\section{HOW TO CITE}

Araújo WA; Assis WC; Vilela ABA, Boery RNSO; Rodrigues VP; Rocha RM. Meanings of living with a chronic wound: a meta-synthesis study. ESTIMA, Braz. J. Enterostomal Ther., 2020, 18: e2420. https://doi. org/10.30886/estima.v18.936_IN

\begin{abstract}
Objective: explore qualitative research on the meanings of living with a chronic wound. Method: it is a qualitative meta-synthesis. 13 articles were included, totaling a sample of 248 individuals who self-reported living with a chronic wound. The Critical Appraisal Skills Program instrument was used to evaluate the eligible articles, and to report the qualitative synthesis, the recommendations of Enhancing transparency in reporting the synthesis of qualitative research were followed. The analysis and extraction of information and construction of the synthesis were carried out by two independent reviewers, with the assistance of a third expert reviewer. Results: living with a chronic wound involves initial concerns and the appearance of symptoms, especially marked pain. They report that the increase in pain led to low functional capacity, as well as weakened social relationships and financial conditions. The experiences illustrate the challenges of emotional burden and the implications of illness, which contributed to social isolation. Religiosity and spirituality were the main coping strategies. Conclusion: living with a chronic wound means a condition of pain, limits physical and functional capacity, causes negative feelings and emotions that result in people's isolation.
\end{abstract}

DESCRIPTORS: Emotions; Stomatherapy; Wounds and injuries; Perception; Life-changing events; Qualitative research.

\footnotetext{
1. Universidade Estadual do Sudoeste da Bahia - Programa de Pós-graduação em Enfermagem e Saúde - Jequié (BA), Brazil.

*Correspondence author: wilkslam@hotmail.com

Received: Aug. 10, 2020 | Accepted: Oct. 06, 2020
} 


\section{RESUMO}

Objetivo: explorar pesquisas qualitativas sobre os significados de viver com ferida crônica. Método: trata-se de uma metassíntese qualitativa. Foram incluídos 13 artigos, totalizando uma amostra de 248 indivíduos que autorreportaram viver com ferida crônica. Utilizou-se o instrumento do Critical Appraisal Skills Programme para avaliação dos artigos elegíveis, e para relatar a síntese qualitativa, seguiram-se as recomendações do Enhancing transparency in reporting the synthesis of qualitative research. A análise e extração das informações e construção da síntese foram feitas por dois revisores independentes, sob o auxílio de um terceiro revisor especialista. Resultados: viver com ferida crônica envolve preocupações iniciais e aparecimento dos sintomas, especialmente dor marcante. Relatam que o aumento da dor levou à baixa capacidade funcional, bem como relações sociais e condição financeira fragilizadas. As experiências ilustram os desafios da carga emocional e das implicações do adoecimento, que contribuíram para o isolamento social. A religiosidade e espiritualidade foram as principais estratégias de enfrentamento. Conclusão: viver com ferida crônica significa uma condição de dor, limita a capacidade física e funcional, provoca sentimentos e emoções negativas que resultam no isolamento das pessoas.

DESCRITORES: Emoções; Estomaterapia; Ferimentos e lesões; Percepção; Acontecimentos que mudam a vida; Pesquisa qualitativa.

\section{RESUMEN}

Objetivo: explorar la investigación cualitativa sobre los significados de vivir con una herida crónica. Método: se trata de una metasíntesis cualitativa. Se incluyeron 13 artículos, totalizando una muestra de 248 individuos que declararon vivir con una herida crónica. Se utilizó el instrumento Critical Evaluation Skills Programme (CASP) para evaluar los artículos elegibles y reportar la síntesis cualitativa, siguiendo las recomendaciones de la Mejora de la transparencia en el reporte de la síntesis de la investigación cualitativa (ENTREQ). El análisis y la extracción de información y la construcción de la síntesis fueron realizados por dos revisores independientes, con la asistencia de un tercer revisor experto. Resultados: convivir con una herida crónica implica preocupaciones iniciales y la aparición de síntomas, especialmente dolor marcado. Informan que el aumento del dolor llevó a una baja capacidad funcional, así como al debilitamiento de las relaciones sociales y las condiciones financieras. Las experiencias ilustran los desafíos de la carga emocional y las implicaciones de enfermarse, lo que contribuyó al aislamiento social. La religiosidad y la espiritualidad fueron las principales estrategias de afrontamiento. Conclusión: vivir con una herida crónica significa una condición de dolor, limita la capacidad física y funcional, provoca sentimientos y emociones negativas que resultan en el aislamiento de las personas.

DESCRIPTORES: Emociones; Enfermeira; Heridas y Traumatismos; Percepción; Acontecimientos que Cambian la Vida; Investigación Cualitativa.

\section{INTRODUCTION}

The chronic wound is a rupture in the integumentary structure with anatomical and physiological changes associated with the prolonged healing process, which can affect individuals of all ages and cause negative impacts on the person's daily life due to its potential to cause changes in skin integrity, itching, pain, exudate and odor $^{1,2}$. Furthermore, it causes direct changes in lifestyle, professional career and body image, constituting a serious problem for the health system ${ }^{3,4}$.

Among the symptoms, pain was the most reported by people who experience the existence of a chronic wound, being aggravated by the prolonged course of healing and threat of recurrence of the injury ${ }^{5}$. The painful wound ends up influencing daily activities, work and leisure, which contributes to low functional capacity, unsatisfactory sleep, emotional instability, suffering, hopelessness and depression ${ }^{6,7}$. In this context, the experience of living with a chronic wound still manifests feelings of worry, guilt, mood swings, frustration, disappointment, anxiety, fear and sadness ${ }^{8,9}$. Other common factors are changes in the relationship with family members, social interaction and increased social isolation. In addition to these feelings, the chronic state leads the person to feel ashamed to show his injured body to others in his social life 5 .

Although injured people want relief and control of symptoms, especially pain, they usually, at the beginning of the illness, deny the existence of the wound and later on come to a time when they accept the chronic condition as an inherent characteristic of their body for the rest of their lives ${ }^{10}$. This has been a frequently cited fact, therefore, caring for people with chronic wounds is one of the challenges for nursing and that needs a greater understanding of the individual's existential dimension ${ }^{11,12}$.

Only three published summaries of qualitative research were found exploring the experience of living with a chronic wound, two aimed at people with leg ulcers ${ }^{13,14}$, and the other, more comprehensive, including all types of chronic wounds, but has limitations in its methodological path ${ }^{15}$. The 
qualitative synthesis involves the comparison and discussion of the results of each qualitative study, in order to generate new interpretations around a common theme ${ }^{16}$. Therefore, it is still necessary to produce this type of study to increase the understanding of the meanings that these people carry and to provide more information aimed at improving and developing nursing practices that facilitate the healing process and promote better living conditions ${ }^{1,11}$.

\section{OBJECTIVE}

Explore qualitative research on the meanings of living with a chronic wound.

\section{METHOD}

It is a qualitative meta-synthesis, based on the following steps proposed by Sandelowski and Barroso ${ }^{17}$ : elaboration of the research question and problem; definition of data search sources and selection of articles; evaluation and analysis of articles; data extraction and synthesis construction. The methodological process was guided by the question asked through the PICO strategy ${ }^{18}$ : what is it like to live with a chronic wound from the perspective of the person affected by these injuries?

A broad and exhaustive literature search was carried out, in order to identify all articles that used a qualitative method to describe the meanings of living with a chronic wound from the perspective of the affected person. The search was conducted by two independent reviewers (WAA and WAC), in the multidisciplinary databases CINAHL, LILACS, PubMed, Scopus and Web of Science. The descriptors and keywords were defined according to the theme of this review in three broad categories: 1) feelings ("emotions", "manifest emotions", "anxiety”, "fear", "guilt”, "hope”, “loneliness”, “ mourning”, “boredom”, “perception”); 2) chronic wound ("wounds and injuries", "skin ulcer", "leg ulcer”, “venous ulcer”, “chronic wound”, "dressings”); and 3) qualitative studies ("qualitative research", "anthropology", "ethnography", "hermeneutics", "phenomenology", "lived experience", "grounded theory"). The crossings between descriptors and keywords were refined and combined with the "AND" operator during the search process, according to each database.
Primary articles available in English, Portuguese and Spanish, using a qualitative method and analysis plan, published between 2014 and June 2019, with male and female individuals (age $\geq 18$ years), who self-reported living with a chronic wound were included. It was stipulated for excluding literature reviews, duplicate articles, studies that addressed burns, as well as those that discussed the experience of the person with a chronic wound from the perspective of family members, caregivers, friends or health professionals. The search of the databases took place in June 2019.

Fig. 1 illustrates the process of searching the literature and including studies, according to the PRISMA recommendations ${ }^{19}$. The total results obtained were 2,158 articles, of which 137 were duplicates, which after being removed, a total of 938 articles were found. Then, two reviewers (WAA and WAC) proceeded to read the titles and abstracts of the screened articles and made their judgments in two stages, the first independently and in a second moment together, eliminating the articles that did not meet the criteria eligibility criteria. As a result of this procedure, 30 articles met these criteria. Kappa's calculation was then performed ${ }^{20}$, to evaluate the level of agreement between observers and the result obtained indicated 0.857 - representing excellent agreement. Soon after, the reviewers performed an independent reading of the 30 eligible articles, and with the help of a third reviewer (RMR), with expertise in qualitative research and in the theme of this article, determined the final eligibility of the articles. After this stage, 17 articles were excluded because of the research method $(n=3)$, considering that these articles focused on the experience they had in relation to the therapeutic method of care $(n=11)$, because they were people with a healed wound, but who suffered a high threat of recurrence $(n=1)$, and because they addressed the context of traumatic injuries $(\mathrm{n}=1)$, as well as surgical wound by second intention $(n=1)$, resulting in a final sample of 13 articles.

It should be noted that articles that included the perception of the person affected by a chronic wound and the caregiver were included in the sample ${ }^{21}$,as the results related to the injured participant were presented separately to those of the caregiver. Likewise, studies that showed individuals with a chronic wound healed followed ${ }^{7,22}$ or that involved diabetic foot ulcers and lower limb amputation in the same sample $e^{23}$. 


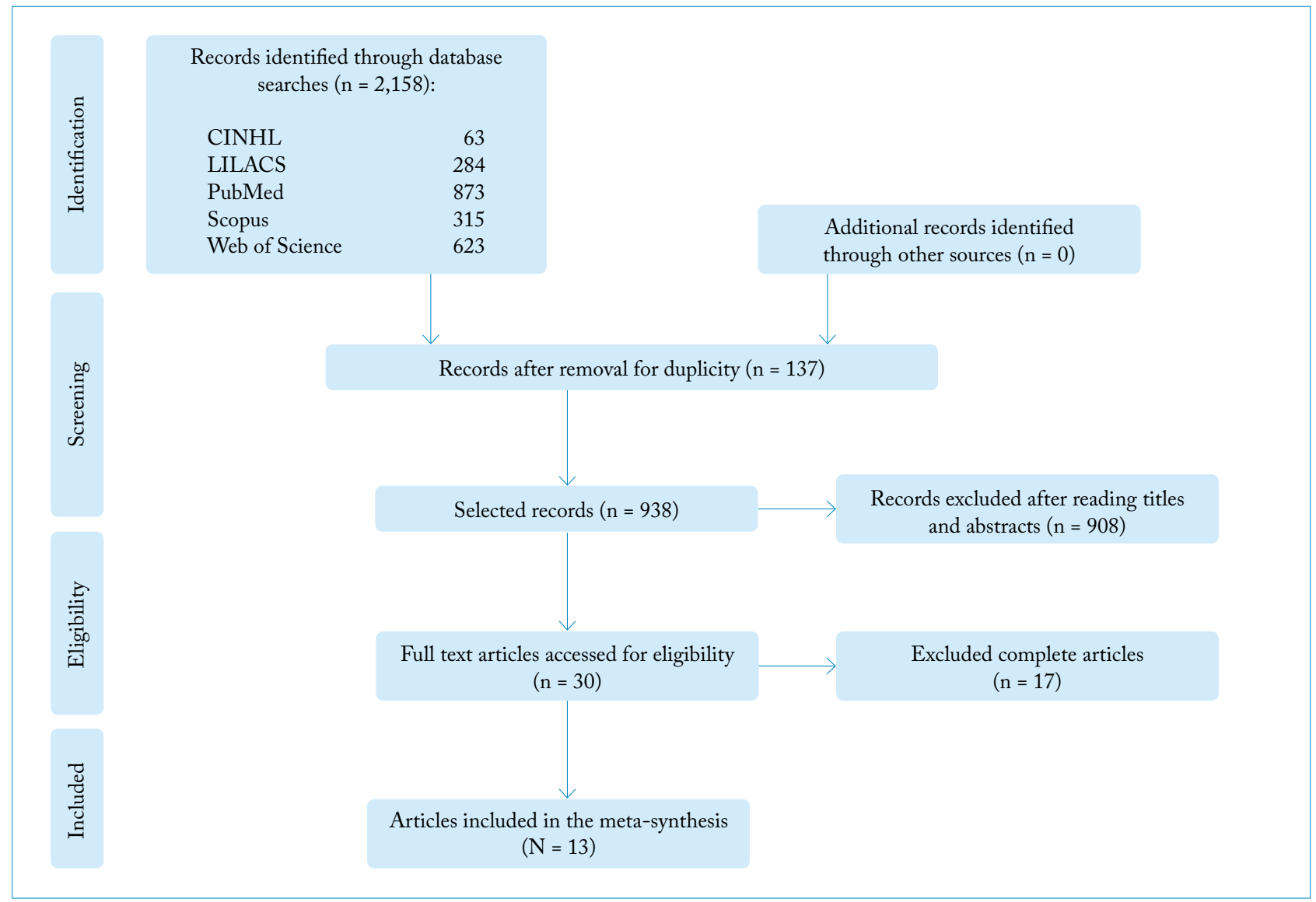

Figura 1. PRISMA flow chart of the literature search process19. Jequié (BA), Brasil - 2019.

The evaluation of the quality of studies in the review was verified using the tools of the Critical Appraisal Skills Program (CASP), which provides a standardized instrument to evaluate the rigor of qualitative studies ${ }^{24}$. Regarding the procedures for reporting the qualitative synthesis, the recommendations described in the Enhancing transparency in reporting the synthesis of qualitative research (ENTREQ) were followed ${ }^{25}$.

In the process of data production and interpretation (extraction and synthesis), both reviewers performed successive readings independent of the complete texts that made up the final sample $(\mathrm{n}=13)$, from which they extracted the information from the articles. In response to the research question, the data were systematized in a standardized electronic form. The form was built collectively and agreed by the research team. Information on authorship, year, country, type of wound in the study, research participants, data production and analysis plan were extracted by reading and evaluating the articles. After, together, the reviewers (WAA and WAC) reassessed all the information extracted, reaching consensus on divergences in the primary assessment. The extraction of information was ended when the reviewers (WAA and WAC) agreed that they had reached the condition of data saturation, without adding new knowledge, that is, without building new themes.

Simultaneously with the information extraction process, coding was carried out, independently, in an inductive way to elaborate the thematic categories related to the meanings of living with a chronic wound, in order to facilitate the synthesis of the data. The codification of the results of the articles was guided by the thematic analysis, composed of the following steps: familiarization of the data; generate the initial codes; explore the search for themes; review the listed themes; define and name the themes; and produce the final report ${ }^{26}$.

Subsequently, the reviewers met to verify, discuss and critically interpret the codes and themes, as well as the concepts related to the categories generated, to resolve any conflict, under the assistance of the third reviewer (RMR), specialist in wound care. The instructions for analysis were followed as faithfully as possible by the study 
team, which included two nurses (RMR and WAA) and a dentist (WAC), who together with three more external nurses (ABAV, RNSOB and VPR) discussed and examined the clinical relevance of emerging themes and conclusions from scientific evidence. Thus, a new interpretation was possible for the results from the primary studies.

\section{RESULTS}

The studies included in the analysis $(n=13)$ were carried out in Brazil $(n=5)$, United States $(n=2)$, United Kingdom ( $n=1)$, Australia $(n=2)$, Denmark $(n=1)$, Italy $(n=1)$ and Sweden $(n=1)$, as described in Table 1 . The 13 articles ${ }^{7,21-23,27-35}$ included a total of 248 participants, most of them female $(n=145)$, aged between 27 and 95 years old and of different ethnicities, who experienced the condition of being affected by venous ulcers ${ }^{27,29,33}$, various chronic wounds $s^{7,28}$, leg ulcers ${ }^{22,30-32,35}$, pressure injury ${ }^{21}$, diabetic foot ${ }^{34}$, as well as individuals with lower limb amputation composing the sample of the same study ${ }^{23}$.

Various qualitative designs were used for data production, including semi-structured interviews ${ }^{21-23,27,29-32,34,35}$, phenomenological interview ${ }^{33}$, in-depth interview ${ }^{7,28}$, drawing-story theme ${ }^{28}$ and focus group interview ${ }^{32}$. The theoretical analysis plan that supported the development of the studies was guided by the assumptions of the

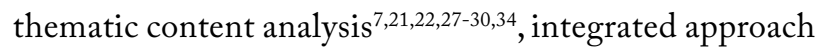
to data coding and analysis through the development of taxonomy, themes and theor $\mathrm{y}^{23}$, grounded theory ${ }^{31}$, phenomenological plan $^{33}$, hermeneutic method ${ }^{32}$ and systematic text condensation ${ }^{35}$.

In general, qualitative studies were considered to be of good quality, as shown in Table 2. Most studies ${ }^{7,21-23,29-32,34}$ $(n=9)$ was judged to report properly all CASP checklist issues $^{24}$. In three studies ${ }^{27,28,35}$ the information related to the recruitment strategy used was not reported properly and, still on the same question, another study did not describe the recruitment of participants ${ }^{33}$. In the study ${ }^{27}$, the data collection information was partially reported and the data analysis was insufficiently rigorous, as well as the relationship between the researcher and the participants was not considered.

The results from the extraction and synthesis of studies on the experiences of people living with chronic wounds were explored and enabled the construction of three main themes, through meta-synthesis: 1) initial concerns and the appearance of symptoms; 2) feelings, emotions and daily confrontations; 3) development of desires and coping strategies. These themes are presented in Table 3 and show the meanings of the experience of living with a chronic wound from the perspective of the affected person.

Table 1. Characteristics of the primary studies included in the meta-synthesis. Jequié (BA), Brasil - 2019.

\begin{tabular}{|c|c|c|c|c|c|}
\hline $\begin{array}{l}\text { Author, } \\
\text { year }\end{array}$ & Country & $\begin{array}{l}\text { Wound } \\
\text { type }\end{array}$ & Participants & $\begin{array}{l}\text { Data } \\
\text { production }\end{array}$ & $\begin{array}{l}\text { Analysis } \\
\text { plan }\end{array}$ \\
\hline $\begin{array}{l}\text { Aguiar, } \\
2014^{27}\end{array}$ & Brazil & $\begin{array}{l}\text { Venous } \\
\text { ulcer }\end{array}$ & $\begin{array}{l}\text { Sample }(n=10) \text { : no details of the } \\
\text { sample are reported. }\end{array}$ & $\begin{array}{l}\text { Semi-structured } \\
\text { interviews }\end{array}$ & $\begin{array}{l}\text { Bardin thematic content } \\
\text { analysis }\end{array}$ \\
\hline $\begin{array}{l}\text { Alves, } \\
2014^{28}\end{array}$ & Brazil & $\begin{array}{l}\text { Chronic } \\
\text { wounds }\end{array}$ & $\begin{array}{l}\text { Sample }(n=45) \text { : study with women. } \\
\text { Age range: } 29-88 \text { years; does not } \\
\text { report the average age. }\end{array}$ & $\begin{array}{l}\text { Drawing-story } \\
\text { theme and in- } \\
\text { depth interview }\end{array}$ & $\begin{array}{l}\text { Content analysis of the } \\
\text { theme-story designs } \\
\text { proposed by Coutinho } \\
\text { and Minayo's thematic } \\
\text { content analysis }\end{array}$ \\
\hline $\begin{array}{l}\text { Alves, } \\
2015^{29}\end{array}$ & Brazil & $\begin{array}{l}\text { Venous } \\
\text { ulcer }\end{array}$ & $\begin{array}{l}\text { Sample }(n=8) \text { : } 4 \text { men, } 4 \text { women. } \\
\text { Age group: there was a prevalence } \\
\text { between } 60-80 \text { years ( } n=5) \text {, the age } \\
\text { of the other participants was not } \\
\text { informed; as well as the average age } \\
\text { was not described. }\end{array}$ & $\begin{array}{l}\text { Structured } \\
\text { interview }\end{array}$ & $\begin{array}{l}\text { Bardin thematic content } \\
\text { analysis }\end{array}$ \\
\hline
\end{tabular}


Table 1. Continuation...

\begin{tabular}{|c|c|c|c|c|c|}
\hline $\begin{array}{l}\text { Author, } \\
\text { year }\end{array}$ & Country & $\begin{array}{l}\text { Wound } \\
\text { type }\end{array}$ & Participants & $\begin{array}{c}\text { Data } \\
\text { production }\end{array}$ & $\begin{array}{l}\text { Analysis } \\
\text { plan }\end{array}$ \\
\hline $\begin{array}{l}\text { Buso, } \\
2016^{30}\end{array}$ & Brazil & Leg ulcers & $\begin{array}{l}\text { Sample }(n=7): 3 \text { men, } \\
\qquad 4 \text { women. } \\
\text { Age group: } 65-86 \text { years; does not } \\
\text { report the average age. }\end{array}$ & $\begin{array}{l}\text { Semi-structured } \\
\text { interviews }\end{array}$ & $\begin{array}{c}\text { Minayo thematic content } \\
\text { analysis }\end{array}$ \\
\hline $\begin{array}{l}\text { Barg, } \\
2017^{23}\end{array}$ & USA & $\begin{array}{l}\text { Diabetic } \\
\text { foot or } \\
\text { lower limb } \\
\text { amputation }\end{array}$ & $\begin{array}{c}\text { Sample }(n=39) \text { : } 24 \text { men, } \\
15 \text { women. Age group: does not } \\
\text { inform; however, the mean age was } \\
60.9 \text { years (SD: } 13.9) \text {. }\end{array}$ & $\begin{array}{l}\text { Semi-structured } \\
\text { interviews }\end{array}$ & $\begin{array}{l}\text { Integrated approach } \\
\text { to data coding and } \\
\text { analysis: development of } \\
\text { taxonomy, themes and } \\
\text { theory }\end{array}$ \\
\hline $\begin{array}{l}\text { Cipolletta, } \\
2017^{31}\end{array}$ & Italy & Leg ulcers & $\begin{array}{l}\text { Sample }(n=21): 9 \text { men, } \\
12 \text { women. } \\
\text { Age range: } 27-78 \text { years; with an } \\
\text { average age of } 55 \text { years. }\end{array}$ & $\begin{array}{l}\text { Semi-structured } \\
\text { interviews }\end{array}$ & Grounded theory \\
\hline $\begin{array}{l}\text { Lernevall, } \\
2017^{32}\end{array}$ & Denmark & Leg ulcers & $\begin{array}{l}\text { Sample }(n=6): 4 \text { men, } \\
\qquad 2 \text { women. } \\
\text { Age group: } 61-77 \text { years; with an } \\
\text { average age of } 69.1 \text { years. }\end{array}$ & $\begin{array}{l}\text { Focus group } \\
\text { interview } \\
(n=4) \text { and } \\
\text { semi-structured } \\
\text { interviews }(n=5)\end{array}$ & $\begin{array}{l}\text { Ricoeur's hermeneutic } \\
\text { method }\end{array}$ \\
\hline $\begin{array}{l}\text { Umeh, } \\
2017^{22}\end{array}$ & USA & Leg ulcers & $\begin{array}{l}\text { Sample }(\mathrm{n}=20): 9 \text { men, } \\
11 \text { women. } \\
\text { Age group: } 29-63 \text { years; with an } \\
\text { average age of } 42.4 \text { years. } \\
\text { Note: two participants had } \\
\text { healed ulcers. }\end{array}$ & $\begin{array}{l}\text { Semi-structured } \\
\text { interviews }\end{array}$ & Thematic analysis \\
\hline $\begin{array}{l}\text { Jackson, } \\
2018^{21}\end{array}$ & UK & $\begin{array}{l}\text { Pressure } \\
\text { injury }\end{array}$ & $\begin{array}{l}\text { Sample }(n=12): 3 \text { men, } \\
\qquad 9 \text { women. } \\
\text { Age range: } 31-92 \text { years; does not } \\
\text { report the average age. }\end{array}$ & $\begin{array}{l}\text { Semi-structured } \\
\text { interviews }\end{array}$ & $\begin{array}{c}\text { Thematic analysis } \\
\text { established by Braun } \\
\text { and Clarke }\end{array}$ \\
\hline $\begin{array}{l}\text { Joaquim, } \\
2018^{33}\end{array}$ & Brazil & $\begin{array}{l}\text { Venous } \\
\text { ulcer }\end{array}$ & $\begin{array}{l}\text { Sample }(n=36) \text { : } 16 \text { men, } \\
\qquad 20 \text { women. } \\
\text { Age range: } 41-84 \text { years; with an } \\
\text { average age of } 65.3 \text { years }\end{array}$ & $\begin{array}{c}\text { Phenomenological } \\
\text { interview }\end{array}$ & $\begin{array}{c}\text { Descriptive } \\
\text { phenomenological from } \\
\text { the Merleau-Pontian } \\
\text { perspective }\end{array}$ \\
\hline $\begin{array}{l}\text { Kapp, } \\
2018^{7}\end{array}$ & Australia & $\begin{array}{l}\text { Chronic } \\
\text { wounds }\end{array}$ & $\begin{array}{l}\text { Sample }(\mathrm{n}=25) \text { : } 12 \text { men, } \\
\qquad 13 \text { women. } \\
\text { Age group: } 52 \text { - } 95 \text { years; with an } \\
\text { average age of } 71 \text { years }\end{array}$ & In-depth interview & $\begin{array}{c}\text { Thematic analysis } \\
\text { established by Braun } \\
\text { and Clarke }\end{array}$ \\
\hline $\begin{array}{l}\text { Palaya, } \\
2018^{34}\end{array}$ & Australia & $\begin{array}{l}\text { Diabetic } \\
\text { foot }\end{array}$ & $\begin{array}{l}\text { Sample }(\mathrm{n}=8) \text { : } 4 \text { men, } \\
\quad 4 \text { women. } \\
\text { Age range: } 48-74 \text { years; with an } \\
\text { average age of } 63.2 \text { years. }\end{array}$ & $\begin{array}{l}\text { Semi-structured } \\
\text { interviews }\end{array}$ & Thematic analysis \\
\hline $\begin{array}{l}\text { Marczak, } \\
2019^{35}\end{array}$ & Sweden & Leg ulcers & $\begin{array}{l}\text { Sample }(n=11): 5 \text { men, } \\
\qquad 6 \text { women. } \\
\text { Age range: } 27-83 \text { years, with an } \\
\text { average age of } 62.5 \text { years. }\end{array}$ & $\begin{array}{l}\text { Semi-structured } \\
\text { interviews }\end{array}$ & $\begin{array}{c}\text { Systematic condensation } \\
\text { of text by Malterud }\end{array}$ \\
\hline
\end{tabular}

$\mathrm{SD}=$ standard deviation. 
Table 2. Evaluation of the quality of the studies included from the Critical Appraisal Skills Program. Jequié (BA), Brasil - 2019.

\begin{tabular}{|c|c|c|c|}
\hline Question & Yes $^{*}$ & $\begin{array}{l}\text { Partially } \\
\text { reported* }\end{array}$ & No* \\
\hline 1.Were the research objectives clearly reported? & 13 & 0 & 0 \\
\hline 2. Is the qualitative methodology adequate? & 13 & 0 & 0 \\
\hline 3. Was the research design adequate to achieve the proposed objectives? & 13 & 0 & 0 \\
\hline 4.Was the recruitment strategy adequate to the research objectives? & 9 & $3^{27-28,35}$ & $1^{33}$ \\
\hline 5. Were the data collected in a way that addressed the research question? & 12 & 127 & 0 \\
\hline 6. Has the relationship between the researcher and the participants been properly considered? & 12 & 0 & $1^{27}$ \\
\hline 7. Have ethical issues been considered? & 13 & 0 & 0 \\
\hline 8. Was the data analysis rigorous enough? & 12 & $1^{27}$ & 0 \\
\hline 9. Were the results reported clearly? & 13 & 0 & 0 \\
\hline 10. Does the research bring contributions? & 13 & 0 & 0 \\
\hline
\end{tabular}

* Number of studies.

Table 3. Themes and synthesis of knowledge from the studies. Jequié (BA), Brasil - 2019.

\begin{tabular}{|c|c|c|}
\hline Themes & & Knowledge synthesis \\
\hline & $\begin{array}{c}\text { Striking feature: } \\
\text { pain }\end{array}$ & $\begin{array}{l}\text { Initially, small lesions appear that do not seem to be a problem. However, later they } \\
\text { cause unbearable pain, burning at the wound site, itching, swelling and discomfort } \\
\text { in the person affected by a chronic wound.7,21-23,27-35 }\end{array}$ \\
\hline $\begin{array}{l}\text { Initial concerns } \\
\text { and appearance of } \\
\text { symptoms }\end{array}$ & $\begin{array}{l}\text { Acceptance and } \\
\text { decision to seek } \\
\text { health services }\end{array}$ & $\begin{array}{l}\text { Initially, they have a feeling of self-efficacy that is associated with increased } \\
\text { symptoms (area of injury, pain, secretions and odors). Even at the beginning, there } \\
\text { is a need to search for information, mainly on the internet, about the wound, as well } \\
\text { as the use of homemade preparations can occur until the moment the individual } \\
\text { observes the chronicity of the wound. Subsequently, with a lack of cure, the } \\
\text { subjects end up accepting the condition of illness, and soon receive encouragement } \\
\text { from the support network (friends or relatives) to seek health care.7,22,30-31,35 }\end{array}$ \\
\hline \multirow[t]{2}{*}{$\begin{array}{l}\text { Feelings, emotions } \\
\text { and daily coping }\end{array}$} & $\begin{array}{l}\text { Change in socio- } \\
\text { cultural, family } \\
\text { and economic } \\
\text { relationship }\end{array}$ & $\begin{array}{l}\text { (a) Physical limitation: increased pain led to decreased mobility, especially in daily } \\
\text { and leisure activities. (b) Social relationships and support network: curiosity towards } \\
\text { the person with a wound triggers weakened social relationships. There is an } \\
\text { effort to hide the wound out of shame and to avoid questioning. In general, the } \\
\text { sick person feels like a burden or dependent on the caregiver in their support } \\
\text { network. (c) Financial condition: unproductive or inability to work, as well as constant } \\
\text { complaints of high drug costs. (d) Sleep, rest and sexuality: difficulty sleeping and } \\
\text { resting; impaired sexuality due to the constant need for clarification for the new } \\
\text { partner; and loss of privacy associated with the requirement for intimate care. All of } \\
\text { these factors contributed to (e) social isolation due to the emotional burden and the } \\
\text { implications of living with a chronic wound7,21-23,27-35 }\end{array}$ \\
\hline & $\begin{array}{c}\text { Demonstrations } \\
\text { involved }\end{array}$ & $\begin{array}{l}\text { Concerns, pain, loss of hope for healing, decreased mood, crying, incapacity, } \\
\text { anguish, fear, anger, guilt, discomfort, shame, insecurity, feeling worthless for life, } \\
\text { stress, suffering, anxiety, depression, attempted suicide and early grief result from } \\
\text { the condition of illness in relation to the chronic wound7,21-23,27-35 }\end{array}$ \\
\hline $\begin{array}{l}\text { Development } \\
\text { of desires and } \\
\text { spirituality as a } \\
\text { coping strategy }\end{array}$ & Coping methods & $\begin{array}{l}\text { (a) Strategies: accepting the condition of the chronic wound and the continued } \\
\text { support of the network (relatives and professionals) were presented as positive } \\
\text { strategies. In general, watching television was the main leisure activity. And religiosity } \\
\text { served as a source of strength and hope, especially when family support was absent. } \\
\text { (b) Desires: to provide support and information about the experience of living with } \\
\text { chronic wounds to others who experience recent illness, and a desire for further } \\
\text { research to investigate therapeutic ways of healing the wound22,27,29,35 }\end{array}$ \\
\hline
\end{tabular}




\section{DISCUSSION}

This study shows that living with a chronic wound is an ongoing process that involves initial concerns, pain, acceptance of the chronic state, daily and lifestyle limitations, different expressions of feelings, emotions, coping strategies and desires that can strengthen willingness to seek healthcare assistance. Each topic and synthesis of knowledge is discussed below.

\section{Initial concerns and appearance of symptoms}

This theme represented the initial concerns of the person with a chronic wound in relation to the appearance of the wound and the appearance of the first symptoms, especially regarding the marked characteristic of pain, the initial acceptance of the illness condition and the decision to seek health services motivated by their network of support. The experience of living daily in pain was a meaning often attributed to people with chronic wounds $s^{7,21-23,27-35}$. Previous studies ${ }^{32,36-38}$ showed that the pain symptom is the most commonly reported by the interviewees, followed by secretions, odors, discomfort, anxiety and depression, which is in accordance with the findings of this meta-synthesis.

The study of Marczak et al. ${ }^{35}$ demonstrated that all respondents were initially unconcerned with the presence of the chronic wound, who mostly opted to perform selftreatment with homemade preparations, according to their own experiences or awaited improvements, however in view of the process of not healing the wound, they began to question themselves and to seek information on the internet and with its support network (family, friends and co-workers). In other words, it was seen that the longer the wound took to heal, the more worried and anxious people became. This phase is experienced with dubious meanings, being more evident in elderly people ${ }^{35}$.

The pain caused by the chronic wound was highlighted in all the studies that composed this meta-synthesis, being described as continuous and with a feeling of unpredictable relief ${ }^{7,22}$. In addition to the pain, people said they felt burning and itching at the wound site, which over the weeks seemed to leave them limited, powerless, frustrated and with interference in the areas of quality of life, which consequently resulted in social isolation ${ }^{28,35}$. The pain increased progressively in relation to the time the wound was not healing, became unbearable and ended up gaining central prominence in people's lives ${ }^{22,34}$.

In this way, studies ${ }^{22,28,35}$ point out that living injured in a chronic state means affecting people's daily activities and having negative thoughts about the painful wound, with some individuals being more affected than others. In younger participants, pain had a strong impact on work and leisure activities ${ }^{35}$. Social isolation was greater in the older age group ${ }^{35}$. With the significance and presence of pain, discomfort and negative thoughts concentrated on the wound it was difficult for people to rest or sleep ${ }^{7,35}$. The reduction in sleep quality has also been observed in other studies ${ }^{28,29,33}$.

\section{Feelings, emotions and daily confrontations}

The painful wound can mean changes in the sociocultural, family and economic relationship of people and generate different manifestations of feelings and emotions. Among the main changes, physical limitation, social relationships and support network, financial condition, sleep, rest, sexuality and social isolation stand out. The changes occurred mainly due to the presence of pain that led most people to reduce their functional capacity, including daily activities such as walking, running, playing sports and leisure activities ${ }^{22,29,30,33,35}$.

It is worth mentioning that screen time watching television was the leisure activity most performed by the interviewees, as well as being restricted at home, accessing the internet and listening to the $\operatorname{radio}^{21,29}$. It is noticed that all these activities can contribute to social isolation and excessive screen time, which ends up contributing to a profile of physical inactivity and physical inactivity, in addition, the latter can be a risk factor for the development of chronic diseases ${ }^{39}$. In general, people affected by a chronic wound had worse physical function and pain interference in daily life ${ }^{22,33,35}$. However, physical movement was sometimes prevented or restricted due to its potential to cause bleeding or wound recurrence ${ }^{22}$.

The support network was important to encourage people to seek health care assistance and to discover the chronic wound. All age groups benefited from the 
support of family and friends, as they were able to help deal with fears ${ }^{35}$. The study ${ }^{35}$ clarifies that living with a chronic wound means being in constant confrontation that involves feelings, emotions and strategies that can lead to the decision to seek a health professional. It is at this point, when looking for health care assistance, that professionals need to offer comprehensive care, meeting the broader and more unique circumstances of people, including the promotion of well-being, quality of life, social inclusion and support that can possibly improve therapeutic adherence and stimulate positive effects on the wound healing process ${ }^{34}$.

In the study ${ }^{34}$, most respondents said they offered some support to other people who face the same chronic condition, however three of them reported that the burden of meanings and limitations caused by the wound ended up limiting their ability to provide emotional help. This inability was in part attributed to the burden of trying to heal or prevent recurrences of the wound. It is suggested that future researches study alternatives to reduce the barriers that exist in the interpersonal support relationship and in emotional well-being, as well as they may try to include interventions that encourage self-care and self-help approaches that are planned, monitored and evaluated by trained professionals ${ }^{34}$. Because it is believed that it can promote independence, improve general wellbeing and reduce care costs for people who have chronic wounds and for the health system ${ }^{7}$. Family and social involvement and interaction with health professionals are fundamental to reduce limitations and provide emotional support for these people ${ }^{28}$, because relationships of trust and friendship can contribute to your clinical recovery ${ }^{33}$.

Employee respondents considered work to be a barrier to seeking health care assistance due to the prioritization of work. However, many people said that work was considered a refuge environment that gave meaning to life and helped to deal with the painful wound ${ }^{35}$. But work activities can be hindered by pain and functional impairment ${ }^{7}$, that many times demanded a withdrawal from work to the detriment of prolonged treatment and the need to leave the service to medical consults and perform daily dressings, these situations end up having repercussions on people's financial reality ${ }^{21,33}$.

Study participants34 said that they sometimes needed financial help from formal or informal sources in their support network. In addition, the acquisition of devices that assist in the treatment of the wound was seen as financially inaccessible by the people who needed it most $^{7,23,33}$. Treatment expenses were often stressful, as they directly interfered with their and their family members' financial stability and economic planning ${ }^{7}$.

Therefore, the costs demanded by the need for wound care caused additional financial dependence for their families and the health system itself ${ }^{30,39}$. This reality needs to be highlighted as a barrier to comprehensive care and has been recurrent in several studies s, $21,28,33-35^{\text {. }}$ Trying to guarantee work performance and financial provision for people sick with wounds certainly favors well-being, social balance, the possibility of continuity of health care and contributes to life satisfaction. ${ }^{28}$. We also observed tensions in the existing intimate relationships because of the chronic condition, where there was a report of difficult conversations with the partners due to the need to always explain and ask the new partner to keep the secret ${ }^{22}$.

In this sense, all these factors contributed to social isolation due to the burden of emotional significance and the unpleasant implications of living with a chronic wound ${ }^{7,21-23,27-35}$.It is observed, in particular, that one of the reasons for the isolation for women is the fact that they are not able to dress as they wish, as they started to hide the wound with their clothes to avoid questioning ${ }^{28,29,40}$, while men ended up absent from their physical and leisure activities $^{19}$. In another study ${ }^{41}$ people reported that they avoided leaving the house due to the embarrassment of always having someone watching their bandages with curiosity. The discomfort of self-image increased with the questions about the wound that accompanied them for a long time ${ }^{21,28}$. Therefore, it is highlighted in this metasynthesis that the chronic wound has the potential to cause profound meanings about the functional, social, emotional, financial capacity and freedom to fulfill personal desires.

The meanings of emotions and feelings are inherent in life and can influence during the course of illness ${ }^{35}$. The wounds caused people to not accept the clinical condition due to the chronic state of the injury ${ }^{31,33}$. It is known that the delay in healing can be caused by a lack of knowledge and lack of wound care, as well as by an attempt to ignore the chronic condition ${ }^{31}$. The interviewees' ability to accept and adapt to the chronicity of the wound was procedural28. In another investigation, acceptance only happened when people were close to healing ${ }^{31}$. 
Respondents found it difficult to explain why their wounds remain unhealed and, consequently, many meanings were expressed, such as: concerns, pain, loss of hope for healing, decreased mood, crying, incapacity, anguish, fear, anger, guilt, discomfort, shame, insecurity, feeling worthless for life, stress, suffering, increased anxiety, depression, suicide attempt and anticipated grief $f^{7,21-23,27-35}$. Concern about wound infection was a common factor among respondents ${ }^{7}$, because they feared and blamed themselves for the development of more serious consequences, such as amputation or death, which triggered greater emotional instability ${ }^{23,34}$. Amputation is considered one of the greatest fears of people with wounds, but also an alternative that brings relief when wound healing is not possible ${ }^{37,38}$. There was a report of attempted suicide associated with emotional burden and limitations of living in a chronic state, such as the interference of the diminished ability to play with children ${ }^{20}$.

In general, everyday life was meant as irritating, exhausting and that routinely makes them act without patience, leading them to act aggressively and violently with the people closest to their support network, whether family members, friends and even professionals of health. The manifestation of irritability is mainly stimulated by the non-acceptance of the wound ${ }^{28}$. Despair was evidenced mainly in the moments when health professionals had already tried different methods of care and treatments associated with their perception of the delay in healing ${ }^{7}$. In addition, they reported loss of independence at the expense of their reduced mobility, requiring the inclusion of family members, partners, caregivers and health professionals in the basic care process, which generated feelings of anguish, emotional instability and affected privacy due to the need of intimate care ${ }^{21,30}$.

People did not want to expose their concerns and low self-esteem, they preferred to internalize their thoughts, feelings and emotions instead of sharing it with their support network ${ }^{31,33,34}$. This isolation due to the limited welfare condition restricted social contacts, leaving them more alone with their problems ${ }^{33}$. They felt it was difficult to live with a wound that did not heal and when added to emotional instability it seemed to potentiate depressive signs ${ }^{35}$. This is confirmed by analyzing the context of social interactions ${ }^{22}$, when many people said they felt like they were always looking to hide from the world because of the wound. The sum of the meanings of feelings and emotions involved in the context of having a chronic wound ended up contributing to social isolation ${ }^{28}$, that can be even more present in the elderly ${ }^{35}$.

In some cases, in the study ${ }^{33}$, fear increased after approaching health services, usually this approach took several weeks or months. The routine of scheduled appointments, referral to specialized care and clarifications from the health team about the wounds generated meanings of concern. Soon, people realized that they had made hasty decisions at the beginning of the illness regarding their current condition, that they had not considered the wounds as something of concern. To Joaquim et al. ${ }^{33}$, physical limitations are related to the signs and symptoms that the chronic wound causes, while feelings and emotions are associated with the condition of living with the chronic wound with the demands of lengthy treatment or interpersonal and isolation relationships.

\section{Development of desires and coping strategies}

People developed meanings of different coping methods, which involved strategies to deal with the painful wound in their bodies, limitations, feelings and emotions that worsened in relation to the time of non-healing.

One of the strategies was religiosity being seen as an alternative to reassure the meaning of the emotional and social burden caused by the wounds, as well as meant a source of divine strength, especially when the family or social support network was absent $\mathrm{t}^{22}$. Spirituality meant a way to find comfort and relief to endure the demands of living with an injured body and pain ${ }^{33}$. Thus, the association of the meanings of religiosity and spirituality contributed to attenuate negative thoughts, feelings and emotions and positively affected their experiences with the condition of chronic pain, in addition to helping in the acceptance of illness and being a source of tranquility ${ }^{22,28}$. Although there was a participant who considered the condition of living with a chronic wound as a punishment from God $^{29}$. Divine belief and hope for healing motivated by faith are important, but over time the person may become disbelieving due to the very chronic character of the wound, which causes delayed healing and numerous recurrences of the injury, which naturally leads the individual to hope for the closure of the wound area ${ }^{28}$. 
Therefore, it is recommended that these people are informed about the pathophysiology of the chronicity of the lesion. It is important to encourage the construction of support networks as a care strategy, because it is already known that the family context and friends can strengthen people's will to have the initiative to seek help and submit to the care and treatment of the wound ${ }^{35}$.

As for desires, participants expressed that further research is needed to understand the pathophysiology of marked pain in wounds, but mainly they want a cure for painful wounds to be found. There was also a desire for medical professionals to come to understand patients as people with their singularities and not as symptoms of the disease ${ }^{22}$. Research institutions immediately need new technologies to manage and control the pain these people experience, or perhaps, if necessary, to change our approaches to pain mitigation ${ }^{32}$. Unfortunately, it is still possible to observe the existence of health professionals who end up prioritizing the care model focused on the disease and not on the individual who needs human care, health knowledge and practices no longer support fragmented approaches to care, which concentrate their conceptions in the disease $\mathrm{e}^{42}$. It is important to offer humanized assistance, with acceptance and respect for the values of the human dimensions of a being charged with meanings of feelings and emotions ${ }^{43}$.

The interdisciplinary involvement of the authors' thematic fields made it possible to incorporate different perspectives of analysis and expansion of the discussion. It is believed that this study contributes to the qualitative literature on the meanings of living with a chronic wound and confirms that people affected by a wound report decreased physical and functional capacity, unbearable pain related to the wound, interference in lifestyle, social isolation, financial instability and decreased emotional well-being. It is pertinent to improve pain management and control, therapeutic methods and the need for interventions that address the emotional and clinical state of these people, as well as the development of health education actions for them, their families and caregivers, in addition to the need to disseminate information to society about the different aspects of living with a chronic wound. Continued commitment from health professionals who care for wounds is important to lessen the negative effects of chronic wounds ${ }^{44}$.
There are limitations to this meta-synthesis that need to be pointed out. In relation to the translation of articles, as difficulties were found in understanding some of the interviewees' reports related to the country's language and cultural issues. In addition, the findings were valued according to the highest frequency of presentation in the studies, mainly due to the way in which the results of the original study were extracted and analyzed. Another possible limitation was regarding the consolidation of studies from different perspectives of analysis and philosophical perspectives, as well as the decision to include studies regardless of the type of wound. Taking these limitations into account, it can be assumed that there were meanings of similar experiences among people who lived with a chronic wound in the selected studies regardless of the type of wound, as seen in other studies ${ }^{7,41}$.

\section{CONCLUSION}

Living with a chronic wound means experiencing constant emotional coping, which starts with initial concerns, the onset of symptoms, especially the pain of marked characteristic, the search for information and health care, changes in interpersonal relationships, which includes family and social life, instability financial and manifestations of sadness, crying, incapacity, anguish, fear, anger, guilt, discomfort, shame, insecurity, feeling of uselessness for life, stress, suffering, increased anxiety, depression, attempted suicide and early mourning. Chronic pain and the burden of meanings in the emotional sphere isolate the person from the outside world and imprison him inside their own wounded body.

The coping strategies were given refuge, tranquility and relief during the course of illness and are based on religiosity and spirituality, which ended up motivating the hope of healing in people. The support network of family members, friends and co-workers meant that the person was encouraged to accept the chronicity of the wound and seek health care assistance. The findings presented here may assist in conducting clinical care and the development of new studies and technologies, especially for pain management and control, reducing wound healing time and reducing social isolation. 
AUTHORS ‘CONTRIBUTION

\author{
Conceptualization: Araújo WA e Assis WC; Methodology:
} Araújo WA, Assis WC e Rocha RM; Investigation: Araújo
WA, Assis WC e Rocha RM;Writing - First version: Araújo WA e Assis WC; Writing - Review \& Editing: Araújo WA, Assis WC, Vilela ABA, Boery RNSO, Rodrigues VP e Rocha RM; Supervision: Rocha RM.

\section{REFERÊNCIAS}

1. Fearns N, Heller-Murphy S, Kelly J, Harbour J. Placing the patient at the centre of chronic wound care: a qualitative evidence synthesis. J of Tissue Viability 2017;26(4):254-9. https://doi.org/10.1016/j.jtv.2017.09.002

2. Gupta S, Andersen C, Black J, Leon J, Fife C, Lantis li JC et al. Management of chronic wounds: diagnosis, preparation, treatment, and follow-up. Wounds: a compendium of clinical research and practice. 2017 Sep; [cited 2019 aug 12]; 29(9):S19-S36. Available at: https://europepmc.org/article/ $\mathrm{med} / 28862980$

3. Lentsck MH, Baratieri T, Trincaus MR, Mattei AP, Miyahara CTS. Qualidade de vida relacionada a aspectos clínicos em pessoas com ferida crônica. Rev Esc Enferm USP 2018;52:e03384. https://doi.org/10.1590/s1980-220×2017004003384

4. Hopman WM, Buchanan M, VanDenKerkhof EG, Harrison MB. Pain and health-related quality of life in people with chronic leg ulcers. Chronic Diseases and Injuries in Canada. 2013; [ci 2019 ago 13]; 33(3):167-74. Available at: https:// europepmc.org/article/med/23735456

5. Joaquim FL, Camacho ACLF, Silva RMCRA, Leite BS, Queiroz RS, Assis CRC. Impact of home visits on the functional capacity of patients with venous ulcers. Rev Bras Enferm 2017 Mar/Apr;70(2):287-93. https://doi.org/10.1590/00347167-2016-0291

6. Renner R, Erfurt-Berge C. Depression and quality of life in patients with chronic wounds: ways to measure their influence and their effect on daily life. Chronic Wound Care Manag Res 2017;4:143-51. https://doi.org/10.2147/CWCMR. S124917

7. Kapp S, Miller C, Santamaria N. The quality of life of people who have chronic wounds and who self-treat. J Clin Nurs 2018 Jan;27(1-2):182-92. https://doi.org/10.1111/jocn.13870

8. Stewart A, Edwards $H$, Finlayson $K$. Reflection on the cause and avoidance of recurrent venous leg ulcers: an interpretive descriptive approach. J Clinical Nurs 2018 Mar;27(5-6):e931-e9. https://doi.org/10.1111/jocn.13994

9. Khunkaew S, Tungpunkom P, Sim J, Fernandez RS. The experiences of people in northern Thailand living with diabetic foot ulcers: a descriptive qualitative study. Pacific Rim International Journal of Nursing Research. 2018; [cited 2020 jun 23]; 22(4):304-18. Available at: https://ro.uow.edu. au/smhpapers1/260/
10. Brown A. Chronic leg ulcers, part 2: do they affect a patient's social life?. Br J Nurs 2005 Oct;14(18):986-9. https://doi. org/10.12968/bjon.2005.14.18.19888

11. Probst $S$, Séchaud $L$, Bobbink $P$, Skinner MB, Weller CD. The lived experience of recurrence prevention in patients with venous leg ulcers: an interpretative phenomenological study. J Tissue Viability 2020 Aug;29(3):176-9. https://doi. org/10.1016/j.jtv.2020.01.001

12. Waidman MAP, Rocha SC, Correa JL, Brischiliari A, Marcon SS. O cotidiano do indivíduo com ferida crônica e sua saúde mental. Texto Contexto-Enferm 2011 out/dez;20(4):691-9. https://doi.org/10.1590/S0104-07072011000400007

13. Briggs $M$, Flemming K. Living with leg ulceration: a synthesis of qualitative research. J Adv Nurs 2007 Aug;59(4):319-28. https://doi.org/10.1111/j.1365-2648.2007.04348.x

14. Phillips P, Lumley E, Duncan R, Aber A, Woods HB, Jones GL et al. A systematic review of qualitative research into people's experiences of living with venous leg ulcers. J Adv Nurs 2018 Mar;74(3):550-63. https://doi.org/10.1111/jan.13465

15. Gomes E, Donoso MTV, Werli-Alvarenga A, Goveia VR. Compreendendo os significados de se conviver com ferida crônica. Rev Enferm Atenção Saúde 2018 ago/set;7(2):17688. https://doi.org/10.18554/reas.v7i2.2396

16. Campbell R, Pound P, Morgan M, Daker-White G, Britten N, Pill R et al. Evaluating meta-ethnography: systematic analysis and synthesis of qualitative research. Health Technol Assess 2011 Dec;15(43):1-164. https://doi.org/10.3310/hta15430

17. Sandelowski M, Barroso J. Handbook for Synthesizing Qualitative Research. New York: Springer Publishing Company; 2007. p.284.

18. Joanna Briggs Institute. Joanna Briggs Institute reviewers' manual: 2008 edition. Adelaide; 2008.

19. Moher D, Liberati A, Tetzlaff J, Altman DG, PRISMA Group. Preferred reporting items for systematic reviews and metaanalyses: the PRISMA statement. Ann Intern Med 2009 Aug;151(4):264-9. https://doi.org/10.7326/0003-4819-1514-200908180-00135

20. Vieira AJ, Garrett JM. Understanding interobserver agreement: the Kappa statistic. Family Medicine. 2005; [cited 2019 jun 03]; 37(5):360-3. Available at: http://www. stfm.org/fmhub/fm2005/May/Anthony360.pdf 
21. Jackson DE, Durrant LA, Hutchinson M, Ballard CA, Neville S, Usher K. Living with multiple losses: insights from patients living with pressure injury. Collegian 2018;25(4):409-14. https://doi.org/10.1016/j.colegn.2017.10.008

22. Umeh $\mathrm{NI}$, Ajegba B, Buscetta AJ, Abdallah KE, Minniti CP, Bonham VL. The psychosocial impact of leg ulcers in patients with sickle cell disease: i don't want them to know my little secret. PloS One 2017 Oct;12(10):e0186270. https://doi. org/10.1371/journal.pone.0186270

23. Barg FK, Cronholm PF, Easley EE, Davis T, Hampton M, Malay DS et al. A qualitative study of the experience of lower extremity wounds and amputations among people with diabetes in Philadelphia. Wound Repair Regen 2017 Sep;25(5):864-70. https://doi.org/10.1111/wrr.12593

24. Critical Appraisal Skills Programme. CASP Qualitative Research checklist. 2013 [cited 2019 jun 03]. Available at: https://casp-uk.net/wp-content/uploads/2018/03/CASPQualitative-Checklist-2018_fillable_form.pdf

25. Tong A, Flemming K, Mclnnes E, Oliver S, Craig J. Enhancing transparency in reporting the synthesis of qualitative research: ENTREQ. BMC Med Res Methodol 2012;12(1):181. https://doi.org/10.1186/1471-2288-12-181

26. Braun V, Clarke V. Using thematic analysis in psychology. Qualitative Research in Psychology. 2006; [cited 2019 jun 06]; 3(2):77-101. Available at: https://www.tandfonline.com/ doi/abs/10.1191/1478088706qp063oa

27. Aguiar ACSA, Amaral L, Reis LA, Barbosa TSM, Camargo CL, Alves MR. Changes in the lifestyle of people with venous ulcer. Revista Cubana de Enfermería. 2014; [cited 2019 jun 09]; 30(3). Available at: http://www.revenfermeria.sld.cu/ index.php/enf/article/view/510/98

28. Alves RM, Carvalho ESS, Santos LM, Oliveira JF, Araújo EM. Ser mulher e ter o corpo ferido: um estudo de representações sociais. Rev Pesqui 2014 out/dez;6(4):1513-24. https://doi. org/10.9789/2175-5361.2014.v6i4.1513-1524

29. Alves JF, Sousa ATO, Soares MJGO. Sentimentos de inclusão social de pessoas com úlcera venosa. Rev Enferm UFSM 2015 abr/jun;5(2):193-203. https://doi. org/10.5902/2179769215425

30. Buso ALZ, Mendonça FTNF, Nunes JS, Ferreira LA, Santos ÁS, Zuffi FB. Perceptions of elderly living with leg ulcer. Biosci J 2016 Sep/Oct;32(5):1373-9. https://doi.org/10.14393/BJv32n1a2016-32738

31. Cipolletta S, Amicucci L. Illness trajectories in patients suffering from leg ulcers: a qualitative study. J Health Psychol 2017 Jun;22(7):932-42. https://doi. org/10.1177/1359105315619224

32. Lernevall LSD, Fogh K, Nielsen CB, Dam W, Dreyer PS. Lived experiences of life with a leg ulcer-a life in hell. EWMA Journal. 2017;17(1):15-21.
33. Joaquim FL, Silva RMCRA, Pereira ER, Garcia-Caro MP, CruzQuintana F. Application of Merleau-Pontyan perspective on the physical and psychological implications of venous ulcers. Rev Bras Enferm 2018 Sep/Oct;71(5):2469-76. http://doi. org/10.1590/0034-7167-2017-0542

34. Palaya J, Pearson S, Nash T. Perception of social support in individuals living with a diabetic foot: a qualitative study. Diabetes Res Clin Pract 2018 Dec;146:267-77. https://doi. org/10.1016/j.diabres.2018.10.016

35. Marczak J, Rembeck G, Petersson E-L, Nordeman L. Patient experiences of living with chronic leg ulcers and making the decision to seek professional health-care. J Wound Care 2019 Jan;28(Sup1):S18-S25. https://doi.org/10.12968/ jowc.2019.28.Sup1.S18

36. Taverner T, Closs J, Briggs M. A meta-synthesis of research on leg ulceration and neuropathic pain. $\mathrm{Br} J$ Nurs 2011;20(Sup12):S18-S27. https://doi.org/10.12968/ bjon.2011.20.Sup12.S18

37. Cwajda-Bialasik J, Szewczyk MT, Mościcka P, Cierzniakowska K. The locus of pain control in patients with lower limb ulcerations. J Clin Nurs 2012;21(23-24):3346-51. https://doi. org/10.1111/j.1365-2702.2012.04163.x

38. Taverner T, Closs SJ, Briggs M. The journey to chronic pain: a grounded theory of olderadults' experiences of pain associated with leg ulceration. Pain Manag Nurs 2014 Mar;15(1):186-98. https://doi.org/10.1016/j.pmn.2012.08.002

39. Ussery EN, Fulton JE, Galuska DA, Katzmarzyk PT, Carlson SA. Joint prevalence of sitting time and leisure-time physical activity among US adults, 2015-2016. Jama. 2018;320(19):2036-38. https://doi.org/10.1001/jama.2018.17797

40. Souza MKB, Matos IAT. Percepção do portador de ferida crônica sobre sua sexualidade. 2010; 18(1):19-24.

41. O'Brien J, Finlayson K, Kerr G, Edwards H. The perspectives of adults with venous leg ulcers on exercise: an exploratory study. J Wound Care 2014 Oct;23(10):496-509. https://doi. org/10.12968/jowc.2014.23.10.496

42. Waidman MAP, Rocha SC, Correa JL, Brischiliari A, Marcon SS. O cotidiano do indivíduo com ferida crônica e sua saúde mental. Texto contexto-Enferm 2011 out/dez;20(4):691-9. https://doi.org/10.1590/S0104-07072011000400007

43. Hecke AV, Verhaeghe S, Grypdonck M, Beele H, Defloor T. Processes underlying adherence to leg ulcer treatment: a qualitative field study. Int J Nurs Stud 2011 Feb;48(2):145-55. https://doi.org/10.1016/j.ijnurstu.2010.07.001

44. Turk DC, Fillingim RB, Ohrbach R, Patel KV. Assessment of psychosocial and functional impact of chronic pain. J Pain 2016;17(9):T21-T49. https://doi.org/10.1016/j.jpain.2016.02.006 